\title{
COST AND REIMBURSEMENT ANALYSIS OF SELECTED HOSPITAL DIAGNOSES VIA ACTIVITY-BASED COSTING
}

\author{
Boris Popesko, Šárka Papadaki, Petr Novák
}

\section{Introduction}

Issues related to analysing the cost and reimbursement of any activities performed, especially within hospital organizations, has lately piqued the interest of academics and practitioners. One possible reason for this is that medical establishments in various countries face the same challenges of limited resources, increasing costs and heightened demands for services. For instance, Chernew [15] states that, for the majority of the post-WWII period, healthcare costs with adjustment for inflation rose at a much faster rate than GDP. Increased demands on the quality and extent of healthcare go hand-in-hand with reduced spending on healthcare systems, primarily caused by the finite resources of the public purse. Under such conditions, hospital organizations are pressurised to effectively manage their activities and outputs on restricted budgets [9]. A similar experience can be observed in developing economies with relatively low health insurance coverage [1].

Insufficient resources at hospitals frequently result in alternative treatments being initiated, with a view towards reducing costs. Even surgery could be affected in the future. Šoltés and Gavurová [26] presented an exhaustive study on how one-day surgery impacts the cost and reimbursement of a hospital under conditions of a specific healthcare system. They highlighted the greater efficiency of oneday surgery over the more traditional form of treatment.

Many papers relating to the cost of hospital operations highlight the importance of measuring the profitability, cost and revenue sources of individual decentralized units, such as individual diagnoses and patients. The ability to accurately gauge the profitability of given diagnoses of patients, which ultimately contribute to overall organizational profitability, is highly dependent on the accuracy of the costing method applied. For instance, Šimrová et al. [25] released a comparative study on the cost and reimbursement of lung-cancer treatment among selected healthcare providers. Cost analysis of individual patients was seen to be highly specific for the relevant hospital departments. The same study detailed the cost of administering incredibly complex lung-cancer treatment, including the numerous subsequent algorithms for said treatment. It also evidenced that the costs of such treatment are often based on different forms of cost estimation, such as social cost and absenteeism [23].

Considering that reimbursements - the main source of revenue for a healthcare establishment - depend mostly on the health policy in place and are the focus of negotiation between the parties involved, e.g. insurance companies, hospitals and state bodies, it is surprising that accurately estimating the cost of a patient or diagnosis is very often overlooked in practice. Many scholars have highlighted the increasing importance of costing methods (cost calculations) within hospital organizations. Cost calculation is fundamental to the process of allocating the cost derived from accounting evidence to organizational cost objects, such as types of diagnoses or patients. By the mid-1990s, some scholars were pointing out the increasing need for a method that would obtain an accurate cost per patient, thereby permitting the identification of actual utilization of resources by individual patients treated with different clinical specialities [9].They also noted that high quality data related to the cost of a patient could facilitate effective decision-making by hospital management. The importance of adopting an appropriate costing method within medical establishments has also been highlighted by other scientific studies [16]. 
The challenge of selecting an applicable costing method for a healthcare organization has been a popular topic these past two decades. The budgets of hospitals chiefly rely on public funding, and the onus for such organizations has been on providing an acceptable level of care within a defined budget, rather than generating profit. Indeed, accurately estimating the costs of the services provided has not been the primary objective of hospital managers. Thorley and Johns [27] state that while there are different levels of cost system design, it seems remarkable that the number of hospitals collecting costs on a more detailed basis remains limited. Relative to other industries, the health care sector still lags behind.

Hospitals in various countries are often legally required, for refunding purposes, to have a predefined cost allocation scheme [10], [19]. This marks them out from other sectors where such a legal obligation does not exist. Cardinaels et al. [5] report that the legal system usually takes the form of step-down allocation of costs from service departments (e.g. laundry facilities, administration, cafeteria, etc.) to revenue generating departments such as acute care, surgery, and laboratories. Sometimes costs are further allocated down to the patient level.

The literature refers to various methods suitable for estimating the cost of patient-related services provided by hospitals. These include the use of average costs obtained from dividing total annual expenditure by patient throughput [3], the use of severity of illness and workload scoring systems [26] and billing systems [12]. Carvalho Jericó and Castilho [6] stated that most hospitals employing cost management systems utilized the absorption method. The benefits associated with absorption costing are broad applicability and ease of use. However, it has often been criticized for inaccuracy. Cao et al. [4] lent weight to this with the statement that the VBC (volume-based costing) method has advantages regarding simplicity, but it tends to give approximate and inaccurate results.

Another problem related to the use of various costing methods in hospital management has been investigated by Riewpaiboon et al. [22]. They commented that different methods resulted in differing calculation outcomes. The issue is that efficiency ends up being compared, as it is unknown what the real effect of different costing methods on variance is.
Gujral et al. [13] wrote that traditional cost accounting methods did not accurately reflect the contribution of indirect costs to individual services. Indeed, they pool all indirect costs and allocate them to the given services in proportion to service volume or direct costs. This approach tends to overestimate the unit cost of high volume services and underestimate the cost of low volume ones. When indirect costs are high, as is often the case in healthcare, the cost of services may be seriously misrepresented.

Due to wide-ranging criticism of absorption costing methods and other traditional costing techniques, many authors extol the virtues of modern sophisticated costing procedures. For instance, Cardinaels et al. [5] state that more progressive costing systems such as Activity-Based Costing (ABC) may facilitate a move towards making cost efficiencies. Study presented by Tucek [28] supports that opinion in connection with the implementation of Business Process Management.

$A B C$, widely recognized since the 1990s, increases the accuracy of cost allocation and the ability to measure the output of organizational activities. The most important difference between traditional costing and $A B C$ is that overhead costs are not allocated using a surrogate allocation base, which often leads to arbitrary allocation [8].

Processes for implementing $A B C$ in healthcare organizations have been developed by many researchers over the years [6], [13], [17], [29]. The approaches taken are relatively diverse, usually restricted to limited application of the method in a medical department. Generally, $A B C$ requires two stages: a. costs are allocated to activities; b. said activities are allocated to a product or service [2]. In other words, if it is possible to measure the cost of activities and estimate the consumption of such activity outputs by an individual cost object, then allocating the true cost accurately via the actual causal factors is facilitated.

One of the earliest studies to consider applying $A B C$ in a hospital was published by Helmi and Tanju [14]. The study calculated the costs of a nursing station for three different types of patient. Later, Ramsey proposed the notion that $A B C$ is not only an accounting system, but also a strategic management tool [21]. As mentioned earlier, many scholars have considered procedures for implementing $A B C$ in healthcare organizations [6], [13], [17], [29]. The 
earliest of these examined an establishmentwide application of $A B C$ in a hospital, even though it honed in on inpatient services [29]. The author stated that outpatient care usually involved a greater number of units of service with a relatively small unit cost, but $A B C$ could still be applied to a few high-volume and highcost yet low-profit outpatient services.

Evidence suggests that $A B C$ provides more detailed cost information on the activities of a hospital, which could typically result in better cost management and in some cases lead to reducing costs. Carvalho and Jeríco support the use of $A B C$ in hospitals, arguing that information generated by $A B C$ significantly contributes to hospital management through engendering planning and managerial control [6]. Cardinaels et al. declare that systems such as $A B C$ may assist endeavours to initiate an efficiency drive. It provides more detailed cost information on the activities of a hospital, which would typically result in greater cost reduction and superior cost management [5].

It is questionable why the method has not been commonly adopted by hospitals worldwide when the benefits of the ABC are so widely accepted by experts. Despite the advantages of $A B C$ application, its utilization by healthcare organizations has been rare [13].

Nevertheless, initiating $A B C$ in such a establishment is hampered by several serious limitations, such as the high complexity of the system, which makes it difficult to actually utilize, creating extreme demands for nonfinancial information [26]. Therefore, the need for some degree of caution exists in advocating the use of $A B C$ in hospitals. Lievens et al. [18], for example, argue that a potential drawback of $A B C$ systems lies in the consumption of time and resources associated with developing and managing the implementation process. Everaert et al. [11] claim that many managers who have tried to implement $A B C$ in their organizations, including healthcare executives, have abandoned the attempt in the face of rising costs and irritation on the part of employees.

Such shortcomings, which have also been noticeable in non-healthcare organizations, are usually solved by simplifying the standard $A B C$ system. This has given rise to methods such as Time-Driven ABC [24], which restricts the use of cost drivers to time drivers or Simplified $A B C$ [4], based on major simplification of the system. The TD-ABC method could be applied in different kinds of organizations for costing purposes. It is useful for example in distribution and logistics organizations, hospitals and healthcare organizations etc. Various studies showed that TD-ABC can solve the aforementioned problems associated with the traditional $A B C$ method. [7]

Another problem related to $A B C$ instigation in healthcare, which is obvious from the diverse approaches documented in the literature, is defining a suitable cost object. For instance, the key cost object outlined by Udpa [29], which is used for cost allocation, is the DRG (diagnosisrelated group). The problem is that, in some situations, applying DRGs as the cost object could result in distortion when they are broadly based and include case types that are nonhomogenous. Vogl [30] states that the most controversial and demanding stage of cost calculation at a healthcare establishment is cost apportioning at the patient level. Estimating the patient cost is crucial for reimbursement purposes. Lin et al. [17] used the individual patient as the cost object, but this again increases the complexity of the system.

The objective of the study herein was to compare the cost of selected types of diagnoses with the reimbursement subsequently received. For cost calculation purposes the authors used the Activity-Based Costing method, in order to bring about different, more accurate cost allocation than permitted by the traditional costing method used at the hospital. The methodology calculated the cost of individual patients, hence analysis also focused on cost variability within the diagnosis-related group. The study is further proof that major differences exist between the calculated cost and eventual reimbursements, a potential cause of which could be lack of knowledge on the cost of the treatments administered.

\section{Methods}

As previously mentioned, the objective herein was to analyse the cost and reimbursement of selected patients and DRG categories in certain hospital departments, in order to discern any possible managerial implications of the given analysis and discuss the consequences of variance between the calculated costs and eventual reimbursements. The authors used the ABC method, so as to calculate the costs of individual patients and DRGs through performing cause-and-effect overhead cost allocation, as explained in the introductory part 
of the study. The research was carried out in three departments at a Czech regional hospital owned by regional municipality, which is typical representative of the regional hospitals. Cost and reimbursement analysis was conducted at an Ear, Nose \& Throat (ENT) department [20], as well as Dermatology and Neonatology departments using data from the fiscal year 2012. The process for selecting the departments and diagnoses for analysis occurred in conjunction with the management team at the hospital, in order to analyse what were considered standard departments of average size, which also maintained a structure of activities and high volume of various treatments. The authors tried to avoid highly complex therapies and diagnoses, and conversely departments and diagnoses carrying out very simple procedures. The general characteristics of the departments are shown in Table 1.

Prior to commencing the standard $A B C$ application, it was necessary to gather all necessary financial and non-financial data required for performing the cost analysis. The documentation and information gathered was as follows:

- Cost reports from financial accounting for the given departments and centres.

- Cost reports from management accounting for said departments and centres.

- Lists of medicines and medical aids supplied to the same.

- Lists of fixed assets with costs and depreciation schedules.

- Technical documentation for construction work.

- Selected invoices.

- Overview of the employees of the departments and their salaries.

- Information on non-financial indicators; e.g. statistics for the following: treatments given, cases of hospitalization, bed-days, procedures, admitted and discharged patients, etc.

\section{Tab. 1: General characteristics of analysed departments}

\begin{tabular}{l|c|c|c}
\multicolumn{1}{c|}{ Case study } & A & B & C \\
\hline Department & Dermatology & Neonatology & ENT \\
\hline Total costs & $16,191,450$ CZK & $46,584,350$ CZK & $18,335,850$ CZK \\
\hline Number of employees & 20 & 94 & 27 \\
\hline Number of beds & 21 & 44 & 26 \\
\hline $\begin{array}{l}\text { Number of hospitalized } \\
\text { patients }\end{array}$ & 456 & 2,593 & 987 \\
\hline Number of activities - primary & 11 & 11 & 11 \\
\hline Number of activities - support & 5 & 5 & 5 \\
\hline
\end{tabular}

Source: own

After the obtaining the necessary data, all typical phases of Activity-Based Costing were conducted, which includes:

- Defining the structure of activities, taking into consideration simplicity of the system and consequent limited number of activities.

- Allocating the cost registered in the accounting system and other additional evidence to defined activities, using varied forms of resource cost drivers.

- Calculating the activity rates for the given activities, using defined cost drivers and activity output measures.

- Calculating costs of selected patients within specific DRG groups.
- Comparing DRG/patient cost and the reimbursement received from the health insurance company.

The cost calculation pertaining to the $A B C$ approach was performed in five consequential stages, as discussed below.

\section{First stage - defining activities}

The initial stage of cost calculation involved defining activities that reflect significant cost pools in the given hospital department. The authors determined a limited number of activities, as the entire $A B C$ system becomes complicated and unclear if numerous activities 


\section{Tab. 2: Standardized structure of proposed primary activities}

\begin{tabular}{l|l|l}
\multicolumn{1}{c|}{ Activity code } & \multicolumn{1}{|c}{ Name of activity } & \multicolumn{1}{c}{ Description of activity } \\
\hline 101 & Outpatient examination & $\begin{array}{l}\text { All standard operations carried out during examination } \\
\text { of the patient at the clinic, except specialized } \\
\text { examinations }\end{array}$ \\
\hline $111-11 \mathrm{X}$ & $\begin{array}{l}\text { Specialized } \\
\text { examination or treatment }\end{array}$ & $\begin{array}{l}\text { Tasks conducted during specialized examinations or } \\
\text { treatment at the department }\end{array}$ \\
\hline 201 & Patient admission & $\begin{array}{l}\text { All standard operations carried out when admitting } \\
\text { the patient to the hospital, including giving a standard } \\
\text { examination; does not involve specialized examinations }\end{array}$ \\
\hline $211-21 \mathrm{X}$ & Hospitalization & $\begin{array}{l}\text { All activities related to a specific instance of } \\
\text { hospitalization, except the cost of treatment(s) }\end{array}$ \\
\hline $221-22 \mathrm{X}$ & Treatments or surgery & All activities related to specialized treatment or surgery \\
\hline 290 & Patient release & $\begin{array}{l}\text { All standard operations carried out at the point of } \\
\text { releasing the patient }\end{array}$ \\
\hline
\end{tabular}

are identified for a department. Therefore, the authors ascertained a standardized structure of activities for each department in order to facilitate the implementation process and permit future comparison of the departments. A general description of these appears in Table 2.

After the primary activities had been defined, it was necessary to discern and describe secondary activities. These took the form of hospital service departments, e.g. X-ray, microbiology or blood transfusion, as these provided services to other primary care departments.
Next, infrastructural activities were ascertained, covering all activities related to administration and infrastructure of the hospital organization. These included: management and administration, management of human resources, information systems and technology and facility management. The costs related to these activities were allocated to the cost object (patients) defined by applying different allocation mechanisms. Here, primary activities were assigned directly to the patients. The costs of secondary activities were consumed by the patient in the primary department that instigated such consumption. In order

\section{Tab. 3: Calculation of the total cost of an activity using the activity cost matrix}

\begin{tabular}{l|c|c|c|c|c|c} 
& activity 1 & activity 2 & activity 3 & $\ldots$ & activity n & $\begin{array}{c}\text { Total of cost } \\
\text { element }\end{array}$ \\
\hline cost element 1 & $\mathrm{X}_{1} \cdot{ }^{*} \mathrm{~K}_{11}$ & $\mathrm{X}_{1} \cdot{ }^{*} \mathrm{~K}_{12}$ & $\mathrm{X}_{1} \cdot{ }^{*} \mathrm{~K}_{13}$ & $\ldots$ & $\mathrm{X}_{1} \cdot{ }^{*} \mathrm{~K}_{1 \mathrm{n}}$ & $\mathrm{X}_{1 .}$ \\
\hline cost element 2 & $\mathrm{X}_{2} \cdot{ }^{*} \mathrm{~K}_{21}$ & $\mathrm{X}_{2} \cdot{ }^{*} \mathrm{~K}_{22}$ & $\mathrm{X}_{2} \cdot{ }^{*} \mathrm{~K}_{23}$ & $\ldots$ & $\mathrm{X}_{2} \cdot{ }^{*} \mathrm{~K}_{2 \mathrm{n}}$ & $\mathrm{X}_{2 .}$ \\
\hline cost element 3 & $\mathrm{X}_{3} \cdot{ }^{*} \mathrm{~K}_{31}$ & $\mathrm{X}_{3} \cdot{ }^{*} \mathrm{~K}_{31}$ & $\mathrm{X}_{3} \cdot{ }^{*} \mathrm{~K}_{33}$ & $\ldots$ & $\mathrm{X}_{3} \cdot{ }^{*} \mathrm{~K}_{3 \mathrm{n}}$ & \\
\hline$\ldots$ & $\ldots$ & $\ldots$ & $\ldots$ & $\ldots$ & $\ldots$ & \\
\hline cost element m & $\mathrm{X}_{\mathrm{m}} \cdot / \mathrm{K}_{\mathrm{m} 1}$ & $\mathrm{X}_{\mathrm{m}} \cdot / \mathrm{K}_{\mathrm{m} 2}$ & $\mathrm{X}_{\mathrm{m}} / \mathrm{K}_{\mathrm{m} 3}$ & $\ldots$ & $\mathrm{X}_{\mathrm{mn}} / \mathrm{K}_{\mathrm{mn}}$ & $\mathrm{X}_{\mathrm{m} .}$ \\
\hline Total of activity & $\mathrm{X}_{.1}$ & $\mathrm{X}_{2}$ & $\mathrm{X}_{3}$ & $\ldots$ & $\mathrm{X}_{.}$ & $\mathrm{X}$ \\
\hline
\end{tabular}

Note: $X_{\text {. }}$ - total of cost element $i$

$\mathrm{K}_{\mathrm{ij}}$ - key to the division of $\mathrm{i}$-th cost element and j-th activity in \% 
to accurately determine the volume of these costs consumed by individual patients, it was necessary to determine the demands of primary departments on the outputs from the relevant secondary departments. This means that it was firstly necessary to allocate the costs of the secondary activities to the primary departments and then to the patients. Finally, the costs of the infrastructural activities were allocated to all the primary and secondary activities.

\section{Second stage - assigning costs to activities}

Once the major activities had been identified, overhead costs were allocated to these defined activities. After performing this step of $A B C$ application, it was possible to determine the total costs of activities. Allocation was made through the resource-cost drivers discerned. Costs were allocated to activities via several resource-cost drivers (RCD), such as the labour consumption of physicians based on activities, and the square metres of floor space given over to activities, etc. All costs were assigned to activities using the "activity cost matrix", which displays links between indirect costs and activities.

\section{Third stage - identifying cost drivers and their output measures}

This phase required defining cost drivers for each activity. Three different types were used, all of which were simply acquirable from the hospital information system. These cost drivers are mostly non-financial in form and represent the activity performance level. Following this, it was necessary to ascertain the output measures of individual activities, i.e. the number of activity units consumed.

Most of the non-financial data could be obtained from medical registers, such as the following reference values:

- Number of tests.

- Number of treatments given.

- Number of patients admitted.

- Number of patients discharged.

- Number of patient days.

- Number of hospitalized patients.

- Number of operations.

- Number of hours.

\section{Fourth stage - determining the unit cost of an activity}

After completing the above stages, it was possible, on the basis of this information, to calculate the unit costs of activities - activity rates. These could be calculated by simple division of the total activity cost by the activity output measure determined. Activity rates can be worked out by the single formula:

$$
\begin{aligned}
& \text { Activity rate }=\text { total activity cost / activity } \\
& \text { output measure }
\end{aligned}
$$

Table 4 displays the activity rates calculated for the neonatology department of the selected hospital.

\section{Fifth stage - calculating the cost of a patient}

This step included calculating the costs of a selected cost object, i.e. a patient. In order to assign the cost to a defined cost object, it was necessary to identify the volumes of individual activity outputs consumed by a specific patient. All necessary data regarding the consumption of activities by individual patients are normally obtainable from the information system of the hospital. Data on the volume of output of activities usually makes up part of the medical reports - the length of hospital stay, number of examinations, etc.

The cost of a patient was calculated as the sum of the direct cost consumed by the patient (usually consisting of material and medicine directly allotted to the specific patient) and the activity cost, calculated as the sum of individual activity rates multiplied by the activity units consumed by the given patient. The following formula illustrates how the total cost of a patient could be calculated:

$$
\mathrm{CoP}_{k}=\mathrm{DCoP}_{k}+\sum_{j=1}^{n} A R_{j} \times A V_{k j}
$$

CoP $P_{k} \quad$ Total cost of patient $k$,

$D C o P_{k} \quad$ Direct cost of patient $k$,

$A R \quad$ Vector of activity rates,

$A V_{k j} \quad$ Volume of activity $j$ consumed by patient $k$. If patient $k$ does not consume activity $j$, then $\mathrm{AV}_{\mathrm{kj}}$ equals 0 .

In order to perform the final cost analysis, the calculated cost of a patient was compared with patient revenue streams, ascertained as being the reimbursement received for the patient from a health insurance scheme. Due to the high number of differing DRGs and individual patients, the authors firstly chose a sample of diagnoses at each department analysed, and 
Tab. 4: Examples of activity rates (dept.: neonatology)

\begin{tabular}{|c|c|c|c|c|c|}
\hline & Activity & Cost driver & $\begin{array}{l}\text { Total activity } \\
\text { costs }\end{array}$ & $\begin{array}{l}\text { Output } \\
\text { measure }\end{array}$ & Activity rate \\
\hline 101 & $\begin{array}{l}\text { Outpatient } \\
\text { examination }\end{array}$ & \# of treatments & $507,650 \mathrm{CZK}$ & 1,269 & $400 \mathrm{CZK}$ \\
\hline 111 & $\begin{array}{l}\text { Specialized examina- } \\
\text { tion - sonography }\end{array}$ & \# of treatments & 255,075 CZK & 305 & $836 \mathrm{CZK}$ \\
\hline 112 & $\begin{array}{l}\text { Blood testing and } \\
\text { vaccination }\end{array}$ & \# of treatments & $1,985,225 \mathrm{CZK}$ & 4,757 & 417 CZK \\
\hline 201 & Patient admission & \# of patients admitted & $1,101,775 \mathrm{CZK}$ & 2,592 & $425 \mathrm{CZK}$ \\
\hline 211 & $\begin{array}{l}\text { Hospitalization - } \\
\text { Physiological Care }\end{array}$ & \# of bed-days & $11,310,150 \mathrm{CZK}$ & 11,948 & 947 CZK \\
\hline 212 & $\begin{array}{l}\text { Hospitalization - In- } \\
\text { termediate Care Unit }\end{array}$ & \# of bed-days & $11,288,225 \mathrm{CZK}$ & 2,685 & 4,204 CZK \\
\hline 213 & $\begin{array}{l}\text { Hospitalization } \\
\text { - Intensive Care Unit }\end{array}$ & \# of bed-days & $11,136,825 \mathrm{CZK}$ & 2,198 & $5,067 \mathrm{CZK}$ \\
\hline 221 & Respiratory support & \# of bed-days & $2,958,500 \mathrm{CZK}$ & 1,645 & $1,798 \mathrm{CZK}$ \\
\hline 222 & Infusion support & \# of bed-days & $1,810,600 \mathrm{CZK}$ & 1,232 & $1,470 \mathrm{CZK}$ \\
\hline 223 & Monitoring & \# of bed-days & $3,311,400 \mathrm{CZK}$ & 4,883 & $678 \mathrm{CZK}$ \\
\hline 290 & Patient release & $\begin{array}{l}\text { \# of patients } \\
\text { discharged }\end{array}$ & $2,306,575 \mathrm{CZK}$ & 2,566 & 899 CZK \\
\hline
\end{tabular}

Source: own

then calculated the cost of a selected sample of patients within these given diagnoses. The costs of individual patients were compared with the reimbursements received from health insurance schemes. Afterwards, the average costs and reimbursements for selected diagnoses were calculated.

\section{Results}

After performing the stages outlined above, all final data were summarized in Table 5. As explained in the methodology part of the paper, three different departments at the hospital were selected for analysis (ENT, Dermatology and Neonatology). Within each of these, the authors chose the most relevant DRGs. For example, three DRGs were determined as suitable from the ENT department, with tonsil surgery and partial deafness being sub-divided into acute and non-acute treatment, meaning a total of 5 DRGs for analysis. Three DRGs were also settled on from the Dermatology department, all of them classified under inpatient and outpatient treatment. The Neonatology department does not function with numerous DRGs, but individual patients (newborns) are appraised independently.

For the purposes of analysis, individual patients were placed under two major categories, with 13 different patient categories (DRGs) being analysed in total. For each form of DRG, the authors selected a sample of 10-30 patients, the cost of whom was separately calculated using the designated $A B C$ system. Table 5 displays the following data: average cost per patient sample; the highest and lowest patient cost; and standard deviation, which highlights cost variability between the given patients. The data also includes figures for average reimbursement per patient, the balance of average cost and reimbursement and cost coverage.

\section{Discussion}

The study presents a comparison of average cost calculated by the Activity-Based Costing method with average reimbursements received, and also analyses the cost variability between 
individual patients within selected diagnoses. Research was carried out in three particular departments, which also took into account their most frequent diagnoses. Calculating the treatment costs of individual patients depends on the given treatment procedure and volumes of consumed activities, which could give rise to significant differences between the costs of individual patients. These could be much more accurately captured by the process oriented Activity-Based Costing method, as used in the study. The method applied also resulted in different cost allocation, leading to differences in the calculated costs of patients.

As can be seen in Table 5, the average cost and reimbursement of the analysed DRGs varied widely. The lowest coverage of cost pertains to acute tonsil surgery in the ENT department, where reimbursement covers just $51 \%$ of the calculated cost. However, reimbursement for a preterm newborn of low obstetric weight exceeds actual cost by almost 2.5 times. These differences hint at limited perception of cost-related information in the process of negotiating reimbursements. Other crucial data relates to variability in the cost of individual patients within the DRG groups. Under such conditions, the varying structure of patients in the sample could significantly influence the average cost calculated.

The study revealed several things of note. For instance, comparing inpatient and outpatient treatment in the Dermatology department shows sufficient reimbursement is received for outpatient treatment but it is insufficient for inpatient treatment. Another interesting aspect is the overpayment for treating preterm newborns in Neonatology.

Studying the differences between the calculated cost and reimbursement allows one to arrive at several conclusions. Firstly, it is obvious that there is major discrepancy between the reimbursement policy and the cost of distinct treatments. Under such circumstances, a specific mix of patients could negatively affect the economy of the healthcare provider. Ideally, reimbursements should precisely reflect the cost of treatment.

\section{Tab. 5: Profitability analysis of the selected DRGs}

\begin{tabular}{|c|c|c|c|c|c|c|c|c|c|}
\hline DPT & DRG & $\begin{array}{c}\text { \# of } \\
\text { patients } \\
\text { in } \\
\text { sample }\end{array}$ & Average cost & Max. cost & Min. cost & $\begin{array}{l}\text { Standard } \\
\text { deviation }\end{array}$ & $\begin{array}{l}\text { Average } \\
\text { reimburse- } \\
\text { ment }\end{array}$ & $\begin{array}{l}\text { Average } \\
\text { balance }\end{array}$ & $\begin{array}{c}\text { Reimbur- } \\
\text { sement / } \\
\text { Average } \\
\text { Cost }\end{array}$ \\
\hline ENT & Endoscopy surgery & 10 & $31,240 \mathrm{CZK}$ & 44,958 CZK & 17,148 CZK & 8,229 CZK & 30,867 CZK & -373 CZK & $98.81 \%$ \\
\hline ENT & Non-acute tonsil surgery & 10 & $21,841 \mathrm{CZK}$ & 25,662 CZK & 20,204 CZK & $1,810 \mathrm{CZK}$ & $14,941 \mathrm{CZK}$ & $-6,900 \mathrm{CZK}$ & $68.41 \%$ \\
\hline ENT & Acute tonsil surgery & 10 & 29,344 CZK & 41,478 CZK & 22,646 CZK & $5,501 \mathrm{CZK}$ & $14,941 \mathrm{CZK}$ & $-14,403$ CZK & $50.92 \%$ \\
\hline ENT & $\begin{array}{l}\text { Non-acute partial } \\
\text { deafness }\end{array}$ & 10 & 10,567 CZK & 12,738 CZK & 8,481 CZK & $1,331 \mathrm{CZK}$ & $11,383 \mathrm{CZK}$ & 816 CZK & $107.72 \%$ \\
\hline ENT & Acute partial deafness & 10 & 9,817 CZK & $13,603 \mathrm{CZK}$ & $6,848 \mathrm{CZK}$ & $2,058 \mathrm{CZK}$ & $11,383 \mathrm{CZK}$ & $1,566 \mathrm{CZK}$ & $115.95 \%$ \\
\hline Dermatology & Psoriasis - outpatient & 10 & 5,475 CZK & $13,661 \mathrm{CZK}$ & 505 CZK & 4,528 CZK & $9,732 \mathrm{CZK}$ & 4,257 CZK & $177.75 \%$ \\
\hline Dermatology & Psoriasis - inpatient & 15 & 24,282 CZK & 37,687 CZK & 6,046 CZK & 8,892 CZK & $17,638 \mathrm{CZK}$ & $-6,644$ CZK & $72.64 \%$ \\
\hline Dermatology & $\begin{array}{l}\text { Varicose Ulcers } \\
\text { - outpatient }\end{array}$ & 10 & $3,808 \mathrm{CZK}$ & $12,857 \mathrm{CZK}$ & 336 CZK & 4,194 CZK & 4,213 CZK & 406 CZK & $110.65 \%$ \\
\hline Dermatology & Varicose Ulcers - inpatient & 15 & 28,369 CZK & $44,641 \mathrm{CZK}$ & 10,907 CZK & 10,383 CZK & 17,429 CZK & $-10,940$ CZK & $61.44 \%$ \\
\hline Dermatology & $\begin{array}{l}\text { Eczema and other } \\
\text { - inpatient }\end{array}$ & 15 & 12,746 CZK & 21,638 CZK & 5,176 CZK & 6,117 CZK & 10,402 CZK & $-2,344$ CZK & $81.61 \%$ \\
\hline Dermatology & $\begin{array}{l}\text { Eczema and other } \\
\text { - outpatient }\end{array}$ & 30 & 753 CZK & 2,589 CZK & 168 CZK & 634 CZK & 602 CZK & $-151 \mathrm{CZK}$ & $79.93 \%$ \\
\hline Neonatology & $\begin{array}{l}\text { Preterm newborn } \\
\text { - low obst. weight }\end{array}$ & 10 & 356,519 CZK & $576,698 \mathrm{CZK}$ & 169,965 CZK & 130,584 CZK & 861,157 CZK & 504,638 CZK & $241.55 \%$ \\
\hline Neonatology & Preterm newborn & 10 & 68,617 CZK & 101,324 CZK & 41,748 CZK & $19,760 \mathrm{CZK}$ & 84,022 CZK & 15,405 CZK & $122.45 \%$ \\
\hline
\end{tabular}


One aspect potentially hindering this is the costing method used. As the Activity-Based Costing approach has been sufficiently tested over the past two decades, prevailing opinion is that it generates superior cost information, compared to traditional volume-based costing methods. However, actual utilization of the method remains very low. Many studies have discussed the hurdles inherent to the $A B C$ adoption process, and come up with various solutions to them, such as applying a simplified TD-ABC method.

Secondly, cost and revenue analysis in business often leads to increased focus being placed on products, customers and segments with a high profitability rate. That means that a traditional company, which is able to accurately analyse the profitability of its various business units, concentrates on developing those which are profitable, restricting somehow any unprofitable ones. However, managing a healthcare organization is very different, not only due to the diversity of the establishment, but also as profitability analysis cannot inform similar managerial business-orientated decisions. Ethical principles are at stake and must be respected. Quite simply, it is impossible to manage a customer (patient) portfolio as all patients are equal in the eyes of the law. Consequently, such establishments are faced with very few options on performing any kind of price negotiation. Often the reimbursement stream from the health insurance system adheres to a fixed, inflexible arrangement, not permitting any negotiation.

Despite such significant limitations in utilizing cost and reimbursement analysis, healthcare organizations could still reap some benefits. The analysis performed and precise data on the costs of patients and DRGs could bring about better understanding of any connections between organizational costs and performed outputs. Hospital managers and physicians would be more able to evaluate the costs of the patients and DRGs analysed. Therefore, it would be possible to make better informed decisions at a managerial level on the forms of treatment offered, the structure of investigation into any issues, and other matters which might be optional. Furthermore, analysing the costs of activities might result in boosting the performance of the same, or furthering utilization of current assets and equipment.

\section{Conclusion}

The research performed herein illustrates how Activity-Based Costing could be used to conduct detailed cost and reimbursement analysis of selected patients and DRGs in hospital organizations. The study showed that $A B C$ could reflect the differences in the treatment process which bring about the variations in cost of distinct patients within the same DRG. The most important benefit of an advanced costing method such as $A B C$ is the ability to calculate more accurately the cost of an individual patient. The method is able to highlight differences between the costs of individual patients under the same diagnosis and their differing demands on hospital activities. Traditional costing systems mostly determine average costs, hence data not applicable for analysing any variance between individual patients. If information is lacking on such cost differences, it is not possible to analyse the causes of those differences. Calculating the cost of an individual patient using the $A B C$ approach may also result in "profitability" analysis or verifying the coverage of costs of patients or the diagnosis types presented in the study. Comparing the calculated cost and revenue (reimbursement) for an individual patient enables the user to discern any types of patient with a diagnosis that could financially benefit the hospital, as well as those for which the necessary expenditure would not be covered. As can be seen, many diagnoses pertain to a low volume of reimbursement, which has a crucial impact on the profitability of a healthcare organization. Identifying the DRGs of patient types of low profit could lead to appropriate managerial decisions being made.

This paper was carried out as part of the NT 12235-3/2011 project Applying modern calculation methods to optimize costs in health care, registered at the Internal Grant Agency of the Ministry of Health, the Czech Republic, (IGA $M Z$ ČR).

\section{References}

[1] ACOSTA, R.S. Effects of Health Insurance Concentration Market on Insurance Coverage in Colombia. Journal of Competitiveness. 2014, Vol. 6, No. 3, pp. 3-19. ISSN 1804-1728. DOI:10.7441/joc.2014.03.01.

[2] BAKER, J.J. Activity-Based Costing and Activity-Based Management for Health Care. 
Gaithersburg, Maryland: An Aspen Publication, 1998. ISBN 0834211157.

[3] BAMS, J.L., MIRANDA, D.R. Outcome and costs of intensive care. Intensive Care Medicine. 1985, Vol. 11, Iss. 5, pp. 234-241. ISSN 1432-1238.

[4] CAO, P., TOYABE, S., AKAZAWA, K. Development of a practical costing method for hospitals. Tohoku Journal of Experimental Medicine. 2006, Vol. 208, Iss. 3, pp. 213-224. ISSN 1349-3329.

[5] CARDINAELS, E., ROODHOOFT, F., VAN HERCK, G. Drivers of cost system development in hospitals: results of a survey. Health Policy. 2004, Vol. 69, Iss. 2, pp. 239-252. ISSN 01688510.

[6] CARVALHO JERICÓ, M., CASTILHO, V. Cost management: the implementation of the activity-based costing method in central sterilizing services. Revista da Escola de Enfermagem da USP. 2010, Vol. 44, No. 3, pp. 734-741. ISSN 1980-220X. DOI: 10.1590/ S0080-62342010000300028.

[7] DEJNEGA, O. Utilization of the Activity Based Costing and the Time-Driven Activity Based Costing Methods in Practice for Process Cost Measurement. Economics Management Innovation. 2010, Vol. 2, No. 1, pp. 11-19. ISSN 1805-353X.

[8] DRURY, C. Management and Cost Accounting. 5th ed. Thomson Learning, 2000. ISBN 1861525362.

[9] EDBROOKE, D.L., STEVENS, V.G., HIBBERT, C.L., MANN, A.J., WILSON, A.J. A new method of accurately identifying costs of individual patients in intensive care: the initial results. Intensive Care Medicine. 1997, Vol. 23, Iss. 6, pp. 645-650. ISSN 1432-1238.

[10] ELDENBURG, L., KALLAPUR, S. Changes in hospital service mix and cost allocations in response to changes in Medicare reimbursement schemes. Journal of Accounting and Economics. 1997, Vol. 23, Iss. 1, pp. 31-51. ISSN 0165-4101.

[11] EVERAERT, P., BRUGGEMAN, W., DE CREUS, G. Sanac Inc.: From ABC to Timedriven $A B C$ (TDABC) - an instructional case. Journal of Accounting Education. 2008, Vol. 26, Iss. 3, pp. 118-154. ISSN 0748-5751. DOI: 10.1016/j. jaccedu.2008.03.001.

[12] FINKLER, S.A. The distinction between cost and charges. Annals of internal medicine. 1982, Vol. 96, Iss. 1, pp. 102-109. ISSN 0003-4819.

[13] GUJRAL, S., DONGRE, K., et al. Activity- based costing methodology as tool for costing in hematopathology laboratory. Indian Journal of Pathology and Microbiology. 2010, Vol. 53, Iss. 1, pp. 68-74. ISSN 0377-4929. DOI: 10.4103/0377-4929.59187.

[14] HELMI, M.A., TANJU, M.N. Activitybased costing may reduce costs, aid planning. Healthcare financial management: journal of the Healthcare Financial Management Association. 1991, Vol. 45, Iss. 11, pp. 95-96. ISSN 07350732.

[15] CHERNEW, M.E., HIRTH, R.A., CUTLER, D.M. Increased spending on health care: how much can the United States afford? Health Affairs. 2003, Vol. 22, Iss. 4, pp. 15-25. ISSN 0278-2715. DOI: 10.1377/hlthaff.22.4.15.

[16] KOYAMA, W. Lifestyle change improves individual health and lowers healthcare costs. Methods of information in medicine. 2000, Vol. 39, Iss. 3, pp. 229-232. ISSN 0026-1270.

[17] LIN, B.Y.J., CHAO, T.H., et al. How can activity-based costing methodology be performed as a powerful tool to calculate costs and secure appropriate patient care? Journal of Medical Systems. 2007, Vol. 31, Iss. 2, pp. 85-90. ISSN 1573-689X. DOI: 10.1007/s10916005-9010-z.

[18] LIEVENS, Y., VAN DEN BOGAERT, W., KESTELOOT, K. Activity-based costing: a practical model for cost calculation in radiotherapy. International Journal of Radiation Oncology Biology Physics. 2003, Vol. 57, Iss. 2, pp. 522-535. ISSN 0360-3016. DOI: 10.1016/ S0360-3016(03)00579-0.

[19] PEDEN, A.L., BAKER, J.J. Allocating physicians' overhead costs to services: an econometric/accounting-activity basedapproach. Journal of health care finance. 2002, Vol. 29, Iss. 1, pp. 57-75. ISSN 1078-6767.

[20] POPESKO, B., NOVÁK, P. ActivityBased Costing Methodology as Tool for Costing in Otorhinolaryngology Department. In: Proceedings of the Finance and the Performance of the Firms in Science, Education and Practice Conference. 2013, pp. 571-579. ISBN 978-80-7454-246-6.

[21] RAMSEY, R. Activity-Based Costing for Hospital. Hospital and Health Service Administration. 1994, Vol. 39, Iss. 3, pp. 38996. ISSN 8750-3735.

[22] RIEWPAIBOON, A., MALAROJE, S., KONGSAWATT, S. Effect of costing methods on unit cost of hospital medical services. Tropical Medicine \& International Health. 2007, 
Vol. 12, Iss. 4, pp. 554-563. ISSN 1365-3156. DOI: 10.1111/j.1365-3156.2007.01815.x.

[23] STANISIC, S., et al. Societal cost savings through bevacizumab-based treatment in nonsmall cell lung cancer (NSCLC). Lung Cancer. 2010, Vol. 69, pp. S24-S30. ISSN 0169-5002. DOI: 10.1016/S0169-5002(10)70135-5.

[24] STOUTHUYSEN, K., DEMEERE, N., ROODHOOFT, F. Time-Driven Activity-Based Costing in an outpatient clinic environment: Development, relevance and managerial impact. Health Policy. 2009, Vol. 92, Iss. 2-3, pp. 296-304. ISSN 0168-8510. DOI: 10.1016/j. healthpol.2009.05.003.

[25] ŠIMROVÁ, J., BARTÁK, M., VOJTÍŠEK, R., ROGALEWICZ, V. The costs and reimbursements for lung cancer treatment among selected health care providers in the Czech Republic. E+M Ekonomie a Management. 2014, Vol. 17, Iss. 3., pp. 74-85. ISSN 1212-3609. DOI: dx.doi.org/10.15240/tul/001/2014-3-007.

[26] ŠOLTÉS, V., GAVUROVÁ, B. The Functionality Comparison of the Health Care Systems by the Analytical Hierarchy Process Method. E+M Ekonomie a Management. 2014, Vol. 17, Iss. 3, pp. 100-117. ISSN 1212-3609. DOI: dx.doi.org/10.15240/tul/001/2014-3-009.

[27] THORLEY, N., JOHNS, E.L. Adoption of costing systems by US hospitals. Journal of Healthcare Management. 1994, Vol. 39, Iss. 4, pp. 521-537. ISSN 0973-0729.

[28] TUČEK, D., TUČKOVÁ, Z., HÁJKOVÁ, M. Utilization Level of Business Process
Management in Czech Enterprises - Objectives and Factors. E+M Ekonomie a Management. 2013, Vol. 16, Iss. 2, pp. 81-98. ISSN 12123609.

[29] UDPA, S. Activity-based costing for hospitals. Health Care Management Review. 1996, Vol. 21, Iss. 3, pp. 83-96. ISSN 03616274. DOI: 10.1097/00004010-19962200000009.

[30] VOGL, M. Improving patient-level costing in the English and the German 'DRG' system. Health Policy. 2013, Vol. 109, Iss. 3, pp. 290-300. ISSN 0168-8510. DOI: 10.1016/j. healthpol.2012.09.008.

doc. Ing. Boris Popesko, Ph.D. Tomas Bata University Faculty of Management and Economy Department of Enterprise Economics popesko@fame.utb.cz

Ing. Šárka Papadaki, Ph.D. Tomas Bata University

Faculty of Management and Economy Department of Enterprise Economics sfialova@fame.utb.cz

Ing. Petr Novák, Ph.D. Tomas Bata University Faculty of Management and Economy Department of Enterprise Economics pnovak@fame.utb.cz 


\section{Abstract}

\section{COST AND REIMBURSEMENT ANALYSIS OF SELECTED HOSPITAL DIAGNOSES VIA ACTIVITY-BASED COSTING}

\section{Boris Popesko, Šárka Papadaki, Petr Novák}

Accurately estimating the cost and reimbursement of individual patients and groups of diagnoses has featured in numerous research studies in recent decades. The ever increasing cost of healthcare services, in contrast with the limited resources available, means hospitals have to utilize more advanced management and economics tools in order to boost their efficiency. Detailed and accurate cost-related information could result in superior decision-making and better resource utilization. The accuracy of calculating costs depends on the costing method used, with traditional methods often giving rise to inaccurate cost allocation.

The study presents analysis of the costs and reimbursements of selected DRGs and patients within three particular departments at a Czech regional hospital (ENT, Dermatology and Neonatology). The costs of the given samples of patients were calculated by a custom ActivityBased Costing $(A B C)$ application, comprising a more appropriate approach than a traditional costing method. The ABC methodology applied enables more accurate cost estimation for individual patients and DRGs, also generating a variety of additional cost-related information which could potentially inform any decision-making process. The study discusses the differences between the cost and reimbursement of individual diagnosis groups and cost variances between distinct patients within the each diagnosis, along with the managerial implications of the information obtained.

Key Words: Costing, hospital management, Activity-Based Costing, patient cost.

JEL Classification: 115, M10, M41.

DOI: 10.15240/tul/001/2015-3-005 